
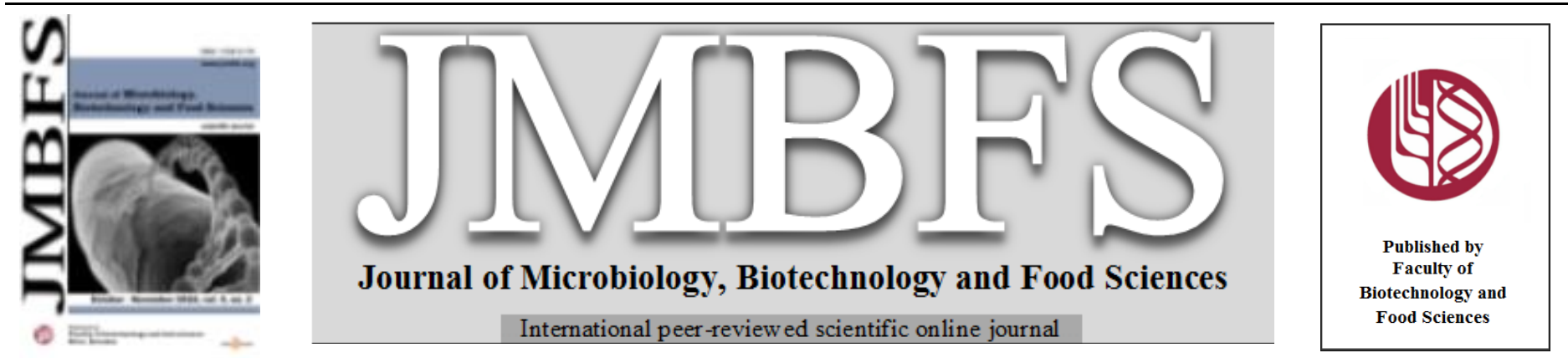

\title{
THE STUDY OF SEASONAL STEROID HORMONES IN MALE SIBERIAN STURGEON (Acipenser baerii) FOR DETERMINING GONADAL DEVELOPMENT STAGES
}

\author{
Najmeh Abbasi $^{1}{ }^{*}$, Ahmad Noori ${ }^{1}$, Mohammad.H. Tolouie Guilani ${ }^{2}$, Bita Kalvani-Neitali $^{3}$ \\ Address(es): \\ ${ }^{1}$ Hormozgan University, Faculty of Marine Science and Technology, Department of fisheries science, Bandar Abbas,3995, Iran. \\ ${ }^{2}$ Shahid Dr. Beheshti Sturgeon Fish Propagation and Rearing Complex, Rasht, Guilan, Iran. \\ ${ }^{3}$ Gorgan University of Agricultural sciences and natural resources, Gorgan, Golestan, Iran.
}

*Corresponding author: abbasi.najmeh@gmail.com

doi: 10.15414/jmbfs.2016.6.2.764-766

ARTICLE INFO

Received 30. 9. 2015

Revised 2. 4. 2016

Accepted 2. 5. 2016

Published 3. 10. 2016

Regular article

open ${ }_{\text {ACCESS }}$

\begin{abstract}
The aim of this study is to investigate of steroid hormones of male Siberian sturgeon in different seasons. For this, blood sampling was taken seasonally from 11 male Siberian sturgeons (7 years old) and then steroid hormones including testosterone and 11-keto testosterone were analyzed by using ELISA. The results showed that testosterone had no significant differences during all the seasons $(p>0.05)$ and the maximum level was in autumn. But 11ketotestesterone had significant differences between winter with other seasons $(\mathrm{p}<0.05)$. The min and max level of 11 ketotestesterone was in autumn and winter, respectively. 11-keto testosterone hormone levels based on sexual maturation stages showed significant difference between stages III and IV with stage II $(\mathrm{p}<0.05)$. Also, there was significant differences between stage II with others in testosterone levels $(\mathrm{p}<0.05)$.
\end{abstract}

Keywords: Siberian sturgeon, testosterone, 11keto testosterone, sex determination

\section{INTRODUCTION}

Sturgeons are the oldest chondrostean fish called alive fossils (Baker et $\boldsymbol{a l}$, 2005). Today, the population of these fish is decreasing because of overfishing, pollution, habitat degradation and dams (Keyvanshokooh et al, 2010; Moghim et al., 2002; Flynn et al., 2006; Billard and Lecointre., 2000). The family of Acipenseridae has economical values such as the expensive caviar production. So from the point of aquaculture, the rearing whole female population is more profitable than mix population (Hassanzadeh Saber et al, 2008; Keyvanshokooh et al, 2010). Among the species of this family, Siberian sturgeon (Acipenser baeri) is one of the species that has advantages including easy adaptation with culture condition, resident to environmental changes (Pyka \& Kolman, 2003), high growth rate, low maturity age and fast caviar production (Adamek et al., 2007). So, to reach a successful management, it is important to know reproduction features (Matsche et al, 2011). A. baerii can reach a maximum length of $2 \mathrm{~m}$ and weight of $210 \mathrm{~kg}$. However, it usually does not exceed $65 \mathrm{~kg}$ in weight with a maximum age of approximately 60 years. The spawning season is from May to June. A. baerii feeds predominantly on benthic organisms including chironomid larvae and river amphipods, isopods and polychaetes (Sokolov and Vasil'ev, 1989).

It is essential to know about sturgeons' reproduction cycle for optima management of stocks and developing diagnostic methods of sex determination in low ages for aquaculture purposes (Petochi et al, 2011). Determining of reproduction status is difficult in sturgeons because they are sexually uniformic and don't have external dimorphism features and as well maturity age is late and have two or more reproduction cycle (Barannikova et al, 2004).

Reproduction in fishes regulates with a cascade of hormones along brainpituitary- gonad called reproductive axis. Nervous gonadotropin releasing hormones directly affect pituitary gland and stimulate FSH and LH secretion. The most important steroid hormones are estradiol and 11-keto testosterone which play major roles in females and males, respectively. In males, 11-keto testosterone is the major regulator of spermatogenesis. FSH acts on sertoli cells and biosynthesises 11-keto testosterone by activating special enzymes like 11- $\beta$ hydroxylase (Cabrita et al., 2008). Therefore, blood sex steroid hormones analysis is another gonadal development method which play important roles in gonadal development (Scholz et al, 2009). As mentioned above, the most important steroid hormones include testosterone (T), 11-keto testosterone (11KT) and 17- $\beta$ estradiol (E2). Plasma levels of these hormones in sturgeons are low before gonadal development stage and show considerable increase of testosterone and 11-keto testosterone levels by the cell division beginning in males. Also, in females and because of oocyte growth, testosterone and 17- $\beta$ estradiol levels increase (Barannikova et al, 2004; Davail- Cuisset et al, 2011). Measuring of plasma sex steroid and glycophospholipoprotein levels has fewer stress compared with surgery and investigating of these hormones can be used in sex and gonadal development stages determination (Craig et al, 2009).

\section{MATERIAL AND METHODS}

\section{Fish and culture condition}

For this purpose, 23 individual of Siberian sturgeon (7 years) randomly selected in Shahid Dr. Beheshti Sturgeon Fish Propagation and Rearing Complex, tagged and transferred to fiberglass tanks $\left(1 \times 1.8 \times 1.8 \mathrm{~m}^{3}\right)$ with $50 \mathrm{~cm}$ water depth. Water temperature was measured $\left(16 \mathrm{C}^{\circ}\right)$.

First, fishes were anesthetized by clove powder $(150 \mathrm{mg} / \mathrm{lit})$ in water, then total length and weight measured by meter and scale, respectively, shown in table 1 . Blood sampling was taken from caudal fin by using none heparinized syringe $(5 \mathrm{ml})$ and samples were centrifuged $(4000 \mathrm{rpm}$ in $10 \mathrm{~min})$ and stored in $-10^{\circ} \mathrm{C}$ ELISA procedure was used for male steroid hormones analysis ( $\mathrm{T} \& 11-\mathrm{KT}$, $\mathrm{ng} / \mathrm{ml}$ ) in endocrine gland research center in Tehran, Iran.

\section{Data analysis}

By general statistic and Excel, total length and weight mean and standard error were calculated. Independent samples t-test was performed to compare mean weight of females and males in each group and mann whitney test for T and 11 KT at 95\% significance level, using SPSS 16.0 software. Data are presented as mean \pm standard error.

\section{RESULT AND DISSCUSSION}

The results showed that there were no significant differences in total length and weight of fish $(\mathrm{p}>0.05)$. In table 1 , total length and weight were given (Mean \pm SEM). The mean values of T and 11-KT are shown in table 2. Testosterone levels were $23 \pm 0.34,22.3 \pm 0.81,23.5 \pm 0.22$ and $22.2 \pm 0.58(\mathrm{ng} / \mathrm{ml})$ and 11 -keto testosterone levels $1.35 \pm 0.36,1.38 \pm 0.48,1.01 \pm 0.23$ and $2.86 \pm 0.4(\mathrm{ng} / \mathrm{ml})$ in spring, summer, autumn and winter, respectively. Testosterone hormone analysis demonstrated that there was no significant difference during all seasons $(p>0.05)$ 
and the highest level was in autumn. But in 11-keto testosterone, there was significant difference between winter with other seasons $(\mathrm{p}<0.05)$ and the highest and lowest levels were in winter and autumn, respectively (table.2).

The result of hormone analysis based on sexual maturity stages showed that testosterone had the highest and lowest levels in stages V and II, respectively (23.97 and $22.54 \mathrm{ng} / \mathrm{ml}$, respectively). There was also significant difference between stage II with other stages $(\mathrm{p}<0.05)$. In other hand, the highest and lowes levels of 11-keto testosterone were in stages III and II $(2.98$ and $1.52 \mathrm{ng} / \mathrm{ml}$, respectively). The results showed that there was significant difference between stages III and IV ( $\mathrm{p}<0.05)($ table.3).

\begin{tabular}{lccc}
\multicolumn{2}{l}{ Table 1The mean of total length and weight of Siberian sturgeon 7 years old } \\
\hline Sex & No. & $\begin{array}{c}\text { Total length }(\mathbf{c m})( \\
\text { Mean } \pm \text { SEM) }\end{array}$ & $\begin{array}{c}\text { Total weight }(\mathbf{k g}) \\
\text { (mean } \pm \text { SEM) }\end{array}$ \\
\hline female & 12 & $100.57 \pm 1.62$ & $4.13 \pm 0.18$ \\
male & 11 & $94 \pm 2.58$ & $3.12 \pm 0.34$ \\
\hline
\end{tabular}

Table 2 Steroid hormone levels in male Siberian sturgeon in different seasons

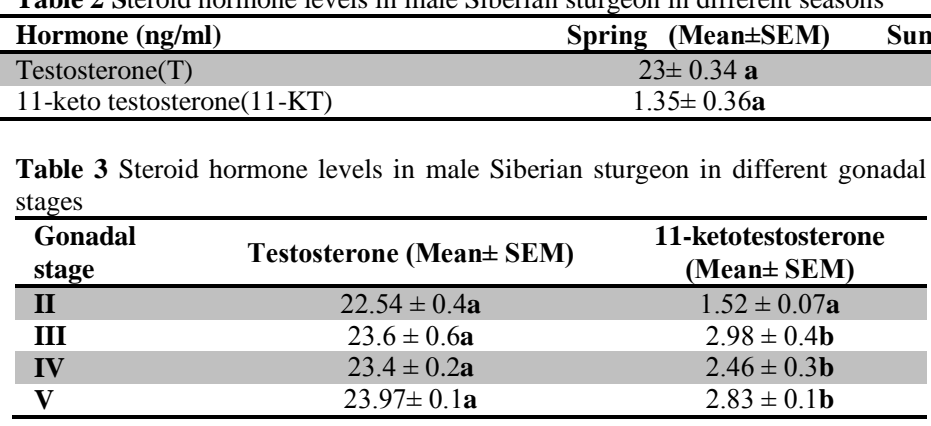

One of the gender and gonadal development stages determination is the measuring of steroid hormones such as testosterone, 11-keto testosterone and estradiol in wild sturgeons. In teleosts, dominant male androgens are testosterone and 11-keto testosterone that testosterone acts as a precursor of 11-keto testosterone and can participate in spermatogenesis process (Aramli et al., 2013) Testosterone and 11-keto testosterone play roles in spermatogenesis and early spermatogenesis, respectively. Also, testosterone with enzymes such as 11- $\beta$ hydroxylase and 11- $\beta$ hydroxysteroid dehydrogenase converts to 11-keto testosterone. During spermatogenesis, androgen levels due to the decreasing conversion of $17 \beta$ - hydroxyprogesteron to androgens and the change in the pathway of steroid to progestin formation decrease (Barannikova et al., 2004).

In this research, 11-KT levels reach highest in winter and demonstrate an increasing trend in spring and summer, then a decreasing in autumn and finally increase in winter. Testosterone had a fluctuation trend during seasons which being increased in spring and autumn and decreased in summer and winter Recently, plasma 11-KT level has been used for determining of immature Siberian sturgeons. According to Cuisset et al (1991), 11-KT level used for immature Siberian sturgeon was $5 \mathrm{ng} / \mathrm{ml}$, fish with $5 \mathrm{ng} / \mathrm{ml}$ or more $11-\mathrm{KT}$ classify as male; and fish with fewer than $5 \mathrm{ng} / \mathrm{ml}$ as female. If the threshold level decreased to $3 \mathrm{ng} / \mathrm{ml}$, immature females classification increases from $5 \%(4 \mathrm{ng} / \mathrm{ml})$ to $9 \%(3 \mathrm{ng} / \mathrm{ml})$ for testosterone and $3 \%(4 \mathrm{ng} / \mathrm{ml})$ to $7 \%(3 \mathrm{ng} / \mathrm{ml})$ for $11-\mathrm{KT}$. Therefore, it seems that $4 \mathrm{ng} / \mathrm{ml}$ of testosterone or $11-\mathrm{KT}$ can be used for immature females and males differentiation, but also should consider the error in immature males classification as female. However, in this paper 11-KT level was $2 / 86 \mathrm{ng} / \mathrm{ml}$

Sex steroids decrease after gonadal development near spawning and post spawning (Craig et al., 2009; King et al., 1994; Rosenblum et al., 1987). In lake sturgeon, sex steroids increase in pre spawning and quickly decrease in post spawning (McKinley et al., 1998). Similar results have been reported in other sturgeons about steroids and vitellogenin (Amiri et al., 1996; Barannikova $\boldsymbol{e}$ al., 2004; Linarse-Casenave et al., 2003).

Despite of special sexual differences in productive hormone levels between male and female, these levels are not completely reliable just because of natura fluctuations during reproductive cycle. Vitellogenin produces in response to estradiol increasing during oocytes growth. Immature and males have much low or no vitellogenin. Wildhabber et al (2007) showed that with reproductive cycle existence, female vitellogenin level is 100 times higher than male. Since males mature in lower ages, and reproduce more than females, it is reasonable that more reproducing males than females exist during spawning cycle (Craig et al., 2009). Although there is difference of steroid levels between species, plasma steroid profile is similar during sturgeon maturing and may be used for determining gender and maturing stages. Although there is error in classification of gender and maturing stages of white sturgeon by using plasma indexes, this method has advantages compared with biopsy (Webb et al., 2002). According to Bagheri $\boldsymbol{e}$ al (2008), the results showed that steroid hormone levels are influenced by gender, and testosterone in males and estradiol and progesterone in females were higher. Hormonal changes depend on environment temperature. The study on immature and mature Acipenser sturio in brackish water showed that the highes steroid hormones levels is testosterone. In immature fishes, estradiol and testosterone levels are so low that likely because of low gonadal development Additionally, they showed seasonal fluctuation in immature fishes. Seasonal fluctuations of steroid hormones were seen not only in mature but also in immature fishes (Davail- Cuisset et al, 2011).

Sex steroid hormone level measurements have little stress compared with surgery. Thus, hormone measuring can be used for determination of gender and gonadal development stage in the fishes (Craig et al., 2009). In Persian sturgeon

\begin{tabular}{lcc}
\hline mer $($ Mean \pm SEM) & Autumn $($ mean \pm sem $)$ & winter $($ mean \pm sem $)$ \\
\hline $22.3 \pm 0.81 \mathbf{a}$ & $23.5 \pm 0.22 \mathbf{a}$ & $22.2 \pm 0.58 \mathbf{a}$ \\
$1.38 \pm 0.48 \mathbf{a}$ & $1.01 \pm 0.23 \mathbf{a}$ & $2.86 \pm 0.4 \mathbf{b}$ \\
\hline
\end{tabular}

(Acipenser persicus) (Viayeh et al., 2006), and shovelnose sturgeon (Scaphirhynchus platorynchus)(Wildhaber et al., 2007), these hormones were reported by more than $90 \%$ accuracy for sexual stage determination. Also, it is reported that testosterone level in male white sturgeons in stage II were higher than females (Webb et al., 2002). This property results in early sex determination in different gonadal development stages. Semenkova et al (2006) confirmed this result but showed that effective and reliable application of this method needs investigating of reproductive status and testosterone, 11-keto testosterone as well as estradiol in different ages of male and females in various farms(pond, circular and warm water). Chebanov and Gallich (2009) stated that one of the endocrine method disadvantage is the high expense in field and laboratory conditions. Blood analysis requires related equipments, fish tagging system and employees for capturing as well as analysis time. However, Sakomoto et al (2001) suggested that changes in blood parameters among fishes can be influenced by other variables including sampling, capturing, correct handling way, captive condition and analysis method.

Acknowledgement: In this paper, we thank to the Shahid Dr. Beheshti Sturgeon Fish Propagation and Rearing Complex boss and their employees for helping and participating in this research.

\section{REFERENCES}

ADÁMEK, Z., PROKEŠ, M., BARUŠ, V., SUKOP, I. 2007. Diet and Growth of $1+$ Siberian Sturgeon, Acipenser baerii in Alternative Pond Culture. Turkish Journal of Fisheries and Aquatic Sciences, 7(2), 153-160.

AMIRI, B.M., MAEBAYASHI, M., HARA, A., ADACHI, S., YAMAUCHI, K 1996. Ovarian development and serum sex steroid and vitellogenin profiles in the female cultured sturgeon hybrid, the bester. J. Fish Biol, 48(4), 1164-1178. http://dx.doi.org/10.1111/j.1059-1996.tb01812.x

ARAMLI, M. S., KALBASSI, M. R., NAZARI, R.M. 2013. Comparative Study of Sex Steroid Levels of Persian Sturgeon, Acipenser persicus Males in Responding Negative and Positive to LHRH-A2 Hormone. J Aquac Res Development, 4(3), 177. http://dx.doi.org/10.4172/2155-9546.1000177

BAGHERI, T., HEDAYATI, A. A., JAFARIAN, A., ASKARI HESNI, M. MOVAHEDINIA, A. 2008. The study of seasonal fluctuation of steroid hormones in great sturgeon (Huso huso) cultured in brackish water condition. Bulg. J. Agric. Sci, 14(4), 432-435.

BAKER, D. W., WOOD, A. M., LITVAK, M. K., KIEFFER, J. D. 2005 Haematology of juvenile Acipenser oxyrinchus and Acipenser brevirostrum at rest and following forced activity. Journal of Fish Biology, 66, 208-221. http://dx.doi.org/10.1111/j.0022-1112.2005.00595.x

BARANNIKOVA, I. A., BAYUNOVA, L. V., SEMENKOVA, T. B. 2004 Serum levels of testosterone, 11-ketotestosterone and oestradiol-17 $\beta$ in three species of sturgeon during gonadal development and final maturation induced by hormonal treatment. Journal of Fish Biology, 64, 1330-1338. http://dx.doi.org/10.1111/j.1095-8649.2004.00395.x

BILLARD, R., LECOINTRE, G. 2000. Biology and conservation of sturgeon and paddlefish. Reviews in fish Biology and fisheries, 10(4). 355-392. http://dx.doi.org/10.1023/a:1012231526151

CABRITA, E., ROBLES, V., HERRAEZ, P. 2008. Methods in reproductive aquaculture: marine and freshwater species. CRC press, Taylor \& Francis group. 17-18pp. ISBN 9780849380532

CHEBANOV, M. S and GALICH, E. V. 2009. Sturgeon hatchery manual. FAO fisheries and aquaculture technical paper. No.558. Ankara. 303 p. ISSN 2070 7010

CRAIG, J. M., PAPOULIAS, D. M, THOMAS, M. V., ANNIS, M. L., BOASE, J. 2009. Sex assignment of lake sturgeon (Acipenser fluvescens) based on plasma sex hormone and vitellogenin levels. J. Appl. Ichthyol, 25 (Suppl. 2), 60-67. http://dx.doi.org/10.1111/j.1439-0426.2009.01289.x

CUISSET, B., PELISSERO, C., NENEZ RODRIGUEZ, J., LE MENN, F. 1991 Use of plasma 11- ketotestosterone for sex determination in Siberian sturgeon Acipenser baeri. In A.P. Scott, S.P. Sumpter, D.E. Kime, and M.S. Rolfe, editors Reproductive physiology of fish (Proceedings of the fourth international symposium) University of East Anglia, Norwich, UK, 272. 
DAVAIL-CUISSET, B., ROUAULT, T., WILLIOT, P. 2011. Estradiol, testosterone, 11-ketotestosterone, 17, 20b-dihydroxy-4-pregnen-3-one and vitellogenin plasma levels in females of captive European sturgeon, Acipenser sturio. J. Appl. Ichthyol, 27, 666-672. http://dx.doi.org/10.1111/j.14390426.2011.01730.x

FLYNN, S. R., MATSUOKA, M., REITH, M., MARTIN-ROBICHAUD, D. J., BENFEY, T. J. 2006. Gynogenesis and sex determination in shortnose sturgeon, Acipenser brevirostrum Lesuere. Aquaculture, 253(1), 721-727. http://dx.doi.org/10.1016/j.aquaculture.2005.09.016

HASSANZADEH SABER, M., BARADARAN NOVEIRI, SH., POURKAZEMI, M., YARMOHAMMADI, M. 2008. Induction of gynogenesis in stellate sturgeon (Acipenser stellatus Pallas, 1771) and its verification using microsatellite markers. Aquaculture Research, 39, 1483-1487. http://dx.doi.org/10.1111/j.1365-2109.2008.02015.x

KEYVANSHOKOOH, S., GHARAEI, A. 2010. A review of sex determination and searches for sex-specific markers in sturgeon. Aquaculture Research, 41, e1e7. http://dx.doi.org/10.1111/j.1365-2109.2009.02463.x

KING, W., THOMAS, P., HARRELL, R. M., HODSON, R. G., SULLIVAN, C. V., 1994. Plasma levels of gonadal steroids during final oocyte maturation of striped bass, Morone saxatillis L. Gen. Comp. Endocrinol, 95(2), 178-191. http://dx.doi.org/10.1006/gcen.1994.1115

LINARES-CASENAVE, J., KROLL, K. J., VAN EENENNAAM, J. P., DOROSHOV, S. I. 2003. Effect of ovarian stage on plasma vitellogenin and calcium in cultured white sturgeon. Aquaculture 221(1), 645-656. http://dx.doi.org/10.1016/s0044-8486(03)00134-0

MATSCHE, M. A., BAKAL, R. S., ROSEMARY, K. M. 2011. Use of laparoscopy to determine sex and reproductive status of shortnose sturgeon (Acipenser brevirostrum) and Atlantic sturgeon (Acipenser oxyrinchus oxyrinchus). J. Appl. Ichthyol, 27, 627-636. http://dx.doi.org/10.1111/j.14390426.2011.01679.x

MCKINLEY, S., VAN DER KRAAK, G., POWER, G. 1998. Seasonal migrations and reproductive patterns in the lake sturgeon, Acipenser fulvescens, in the vicinity of hydroelectric stations in northern Ontario. Environmental Biology of Fishes, 51, 245-256. http://dx.doi.org/10.1023/A:10074930228238

MOGHIM, M., VAJIHI, A.R., VEHKINI, A., MASOUDIFARD, M. 2002 Determination of sex and maturity in Acipenser stellatus by using ultrasonography. J. Appl. Ichthyol, 18(4-5), 325-328. http://dx.doi.org/10.1046/j.1439-0426.2002.00423.x

PETOCHI, T., DI MARCO, P., DONADELLI, V., LONGOBARDI, A. CORSALINI, I., BERTOTTO, D., FINOIA, M.G., MARINO, G. 2011. Sex and reproductive stage identification of sturgeon hybrids (Acipenser naccari $\times$ Acipenser baerii) using different tools: ultrasounds, histology and sex steroids. J. Appl. Ichthyol, 27, 637-642. http://dx.doi.org/10.1111/j.1439 0426.2011.01715.X

PYKA, J., KOLMAN, R. 2003. Feeding intensity and growth of Siberian sturgeon Acipenser baerii Brandt in pond cultivation. Arch. Pol. Fish, 11(2), 287 294.

ROSENBLUM, P. M., PUDNEY, J. P., CALLARD, I. P. 1987. Gonadal morphology, enzyme histochemistry and plasma steroid levels during the annua reproductive cycle of male and female brown bullhead catfish, Ictalurus nebulosus Lesueur. J. Fish Biol, 31, 325-341. http://dx.doi.org/10.1111/j.10958649.1987.tb05239.x

SAKOMOTO, K., LEWBART, G.A., SMITH, T.M. 2001. Blood chemistry values of juvenile Red pacu, Piaractus brachypomus. Vet Clinical Pathol, 30(2), 50-52. http://dx.doi.org/10.1111/j.1939-165x.2001.tb00257.x

SCHOLZ, S., and KLÜVER, N. 2009. Effects of endocrine disrupters on sexual, gonadal development in fish, sexual development 3(2-3), 136-51. http://dx.doi.org/10.1159/000223078

SEMENKOVA, B., BAYUNOVA, L., WEBB, M., KOLMAKOV, N. ROMANOV, A., BARANNIKOVA, I. 2006. Effect of progestins on germinal vesicle break down in sturgeon follicles in vitro. J Appl Ichthyol, 22, 353-357. http://dx.doi.org/10.1111/j.1439-0426.2007.00983.x

SOKOLOV, L. I., VASILEV, V. P. 1989. Acipenser baerii Brandt In:J.Holêik(ed). The freshwater fishes of Europe Vol.I, Pt II. General introduction to fishes, Acipenseriformes, AULA- Verlag, Wiesbaden, 263-284 pp.

VIAYEH, R. M., WEBB, M. A. H., HALLAJIAN, A., KAZEMI, R., YALI, M P. 2006. Biochemical and morphometric parameters as indicators of sex and gonadal stages in maturing Persian sturgeon, Acipenser persicus. J. Appl. Ichthyol. 22, 364-368. http://dx.doi.org/10.1111/j.1439-0426.2007.00986.x

WEBB, M. A. H., FEIST, G. W., FOSTER, E. P., SCHRECK, C. B., FITZPATRICK, M. S. 2002. Potential classification of sex and stage of gonadal maturity of wild white sturgeon using blood plasma indicators. T. Am. Fish. Soc, 131(1), 132-142. http://dx.doi.org/10.1577/1548-8659

WILDHABER, M. L., PAPOULIAS, D. M., DE LONAY, A. J., TILLITT, D. E., BRYAN, J. L., ANNIS, M. L., 2007. Physical and hormonal examination of Missouri River shovelnose sturgeon reproductive stage: a reference guide. $J$. Appl. Ichthyol. 23, 382-401. http://dx.doi.org/10.11111/j.1439 0426.2007.00878.x 